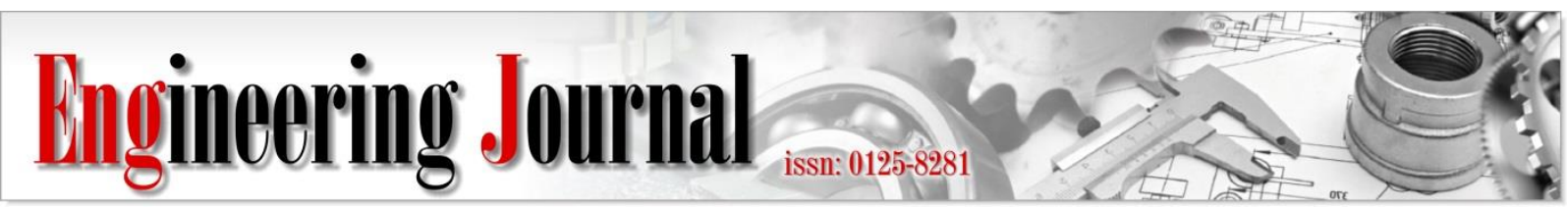

Article

\title{
Land Value Capture Modeling In Residential Area Using Big Data Approach Method
}

\author{
Mohammed Ali Berawi ${ }^{1,}$, Lusi Aprianti ${ }^{1}$, Gunawan Saroji ${ }^{1}$, Mustika Sari $^{1}$, Perdana Miraj, \\ and Amy A. Kim ${ }^{2}$ \\ 1 Department Civil Engineering Department, Faculty of Engineering, Universitas Indonesia, Kampus UI \\ Depok, Depok 16424, Indonesia \\ 2 Department of Civil and Environmental, University of Washington, Seattle, WA 98195, United States \\ *E-mail: maberawi@eng.ui.ac.id (Corresponding author)
}

\begin{abstract}
The increase in the number of train ridership in Jakarta induced the government in constructing more rail infrastructures for example Light Rail Transit as a new option. However, this project is not supported by sufficient funds. Therefor new funding sources are needed to include all process which comprises of development, operation, and maintenance. Land Value Capture modeling is one of such solutions because it refers to the idea that all portions of land which arises from the presence of public infrastructure need to be returned. This research was carried out to obtain hedonic price modeling as a basic reference in capturing land values, by identifying variables that affect the increase of residential property prices obtained using big data approach and web scraping techniques. The result acquired from scraping Lamudi.co.id and Rumah.com websites was 1,237 properties located in South Jakarta. Furthermore, by plotting ArcGIS, 105 data located in catchment areas about $1 \mathrm{~km}$ from LRT line Dukuh Atas-Cawang station were obtained following Transit-Oriented Development (TOD) standard. According to the calculated SPSS, the increase in residential property value was approximate to the mall and CBD area with significant values of 0.845 and 0.819 , which indicate a highly potent correlation.
\end{abstract}

Keywords: Land value capture, hedonic price model, transit-oriented development, data mining.

ENGINEERING JOURNAL Volume 24 Issue 4

Received 5 December 2019

Accepted 21 April 2020

Published 31 July 2020

Online at https://engj.org/

DOI:10.4186/ej.2020.24.4.249

This article is based on the presentation at The 4th International Tropical Renewable Energy Conference (i-TREC 2019) in Bali, Indonesia, 14 - 16 August 2019. 


\section{Introduction}

Based on the data acquired during the last four years, the amount of train passengers from 2015-2017 increased by $18 \%$ in Jabodetabek, Non-Jabodetabek (Jawa) and Sumatera [1]. However, in July 2018 the amount escalated to 242,936 passengers and has increased in the last year. Meanwhile, in June 2018, other rail transportation modes along with the Commuter Line (KRL) became a concern in Jabodetabek area, and it increased to 1.001.438 passengers a day [2]. This appearance occurred because passengers feel more effective using train than other public means of transportation not only owing to its cost efficiency but also due to its prompt travel rate. The previously mentioned merits led the government to construct more rail infrastructure in various regions in Indonesia.

Furthermore, the government contrives to actualize a sustainable transportation system which might affect and accelerate economic growth. According to National Strategic Projects (PSN), there are 23 railway projects with a 3,258 km lane, one of which is the Light Rail Transit (LRT) project construction corresponding to Presidential Law (Perpres) No. 98 of 2015 (see Fig. 1).

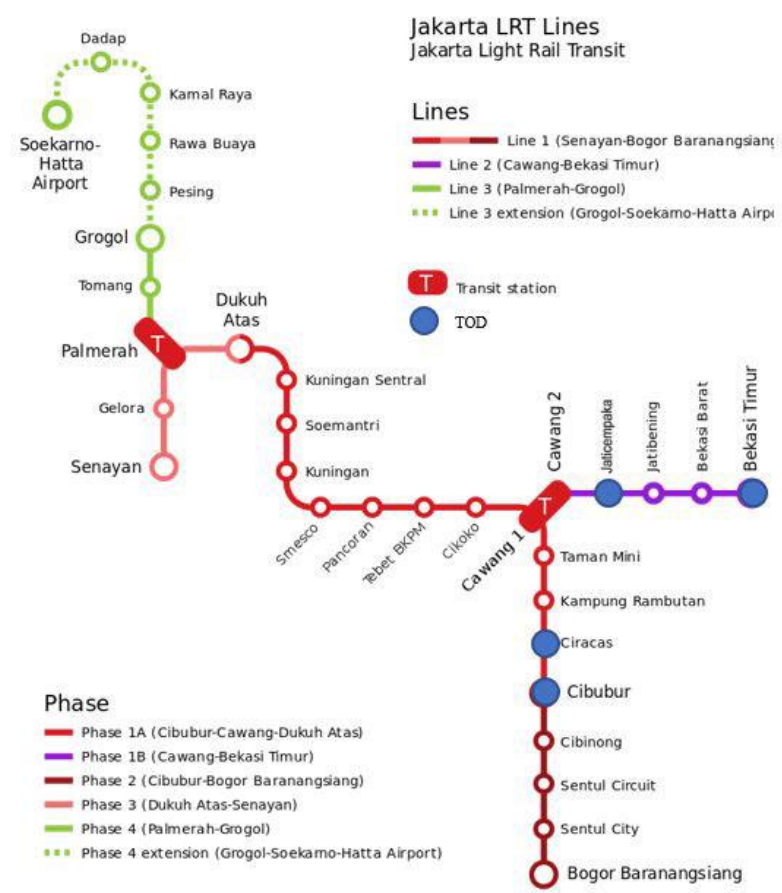

Fig. 1. Jakarta LRT routes and phases of development. (Source: lrtjabodetabek.com.)

Furthermore, the government provided 4.8 quadrillion in the Medium-Term National Development Plan (RPJMN) from 2015-2019 while Directorate General of Budget Financing and Risk Management (DJPRR) contributed only 1.528 trillion or about $28 \%$ were used to finance the total budget for infrastructural development.

The surrounding area is impacted by infrastructural developments including the price of the residential regions based on land value analysis conducted by Bank Indonesia (BI), from 2016 to 2018 with a total number of Housing
Index reaching 206.89 (See Fig. 2). According to the econometric model by 2020, the projected growth value would reach 216.6 [3]. This makes the basis of residential investment property to generate high income in the future. Therefore, housing development also needs an increment. One of the continuing causes of the Housing Property Index is also related to the development of public infrastructure, accessible by house owners to support the ease of activities. However, the problem associated with this strategy is that mostly only developers can earn benefits, while the government has to pay the required budget for development, operations, and maintenance.

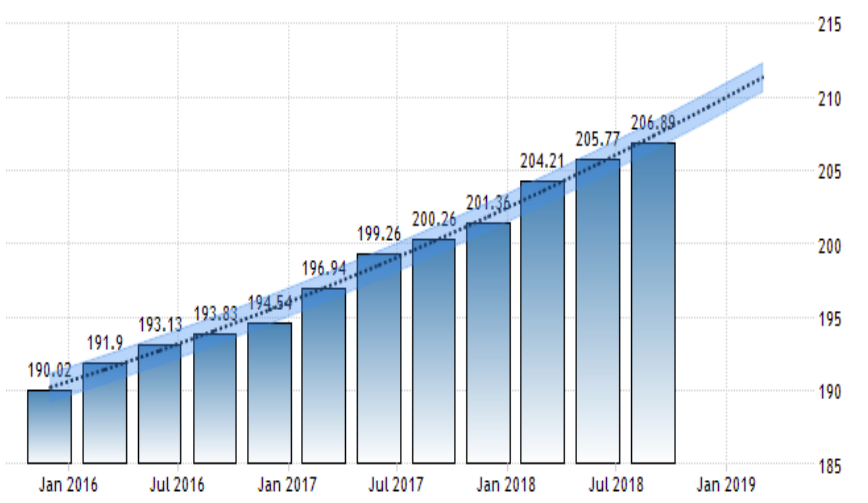

Fig 2. Indonesia's residential property price index. (Source: tradingeconomics.com; Bank Indonesia.)

The transit service in several countries and the funding infrastructure system are dependent on public subvention for operational as well as maintenance cost [4]. Land Value Capture approach is a funding solution as it refers to the idea that the number of land value which arises from the existence of public investments belonging to the public sector needs to be returned [5]. As applied in Santa Clara Country, land value capture method with hedonic price modelling resulted to $23 \%$ value uplift for commercial properties around $1 / 4$ miles from light rail station and $120 \%$ for commercial and businesses from the commuter station [6]. Certain literature showed different land uplift result values due to the city's characteristics, methodology and data study limitation, but in general, they provided significant residential price increase of around $25 \%$ [7].

This research therefore aims to examine the basic of TOD strategy that capitalizes the effect or proximity of LRT station capable of affecting property price. Therefore, the hedonic price model was constructed based on variables that impact on increasing land value for residential properties owing to the existence of railway infrastructure. The variable is used as a reference to determine values captured to transit infrastructure finance.

\section{Literature Review}

This section described the theoretical research in general, by assisting in contriving the research aim, variables, and components. 


\subsection{Railways Infrastructure Theory}

Railways infrastructure systems are one of the national assets that influence the economy of a country [8]. Therefor it is substantially and sustainably supported by investment. Besides, developed railway infrastructure affects land value more than highways [9].

The benefits, associated with transit infrastructure give rise to residential development, generate new jobs and business opportunities, reduce congestion and pollution, and increase the price value of selling or renting properties [10]. These benefits occur by the increased ease connectivity that establishes due to the presence of rail infrastructure in inaccessible locations [11]. Several studies show that increased accessibility due to the construction of transit infrastructure in an area, gives the effect of increasing property values that are greater than other regions with the same conditions but without facilitating the transit infrastructure [12]. The results of the study [4] suggest that the effect of increasing residential property values occurs at a radius of 300 meters and 1000 meters from the transit station by $6.6 \%$ and $5.2 \%$ respectively. As for the increase in the value of office property in a radius of 600 meters from the station by $11.6 \%$ and a radius of 300 meters for commercial by $14.7 \%$. In Mumbai there was an increase in the value of residential property by $14 \%$ in the catchment area $1-2 \mathrm{~km}$ from the Mumbai metro station [13]. Meanwhile the results of study [14] found that the effect of railway stations on commercial property value mainly takes place at short distances. Commercial properties within $1 / 4$ mile rang are $12.2 \%$ more expensive than residential properties. Where the price gap between the railway station zone and the rest is about $4.2 \%$ for the average residence, it is about $16.4 \%$ for the average commercial property. At longer distances the effect on residential property values dominate, where for every 250 $\mathrm{m}$ a residence is located closer to a station its price is $2.3 \%$ higher than commercial properties [14]

On the other hand, the results of research on the effect of the existence of transit stations on residential property values in Atlanta in 1991 showed that properties within a quarter of a mile from a rail station were found to sell for $19 \%$ less than properties beyond three miles from a station. However, properties that are between one and three miles from a station have a significantly higher value compared to those farther away. These results suggest that houses that are very close to stations are affected by negative externalities, but those at an intermediate distance are beyond the externality effects and benefit from the transportation access provided by the stations [15].

\subsection{Urban Development Theory}

In the next 40 years, the population is estimated to increase by 5.5 million people per month [16], with an effect on the economic sector and social condition accompanied by adequate basic service level. Some major cities in Asia, are not capable of accommodating the basic urban services such as water supply, better waste collection system, and other public infrastructures [17]. However, the Urban Development concept should overcome the problem due to population growth and urbanization by developing or increasing its area to improve the existing locality [18].

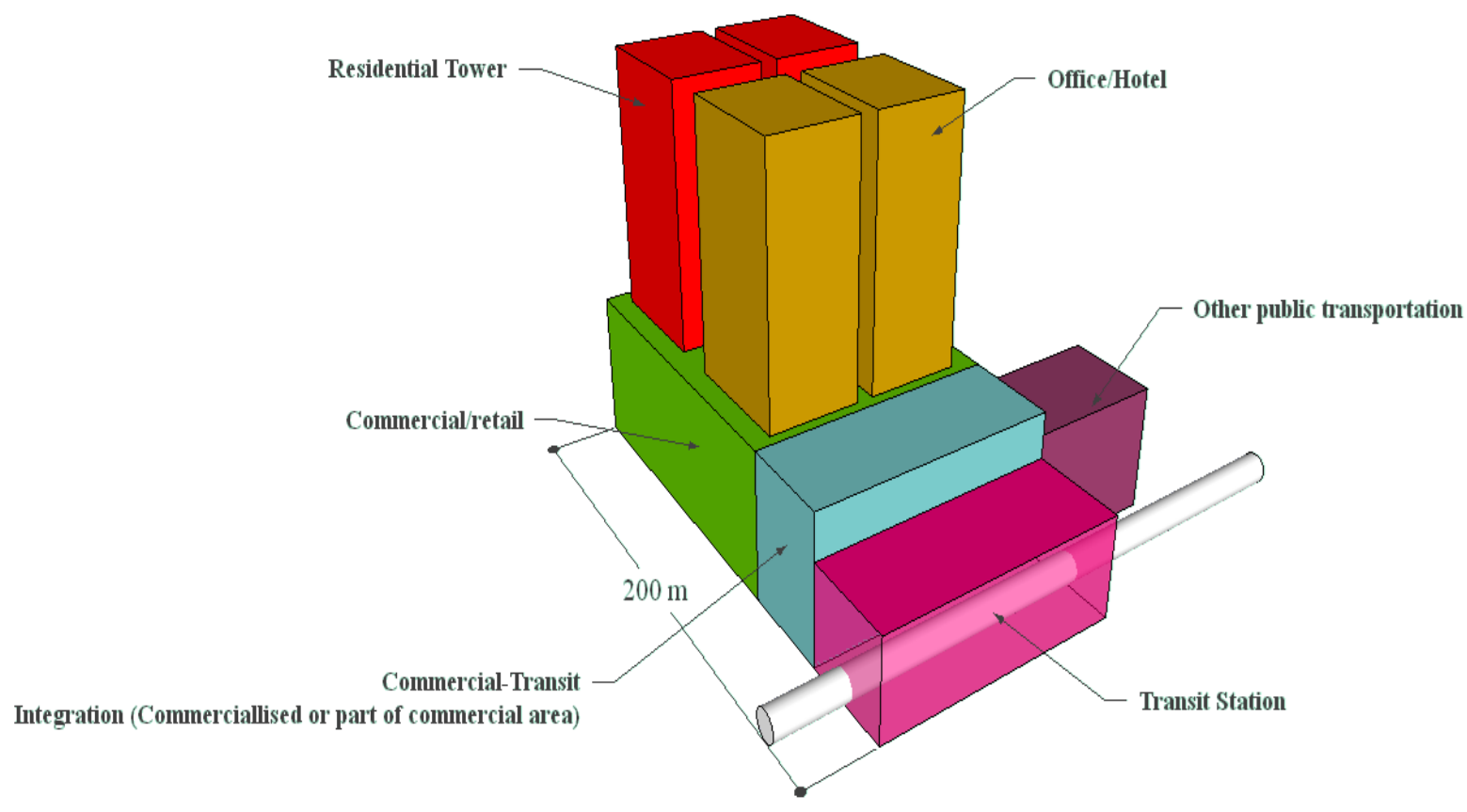

Fig. 3. TOD model. (Source: CSID, 2019.) 


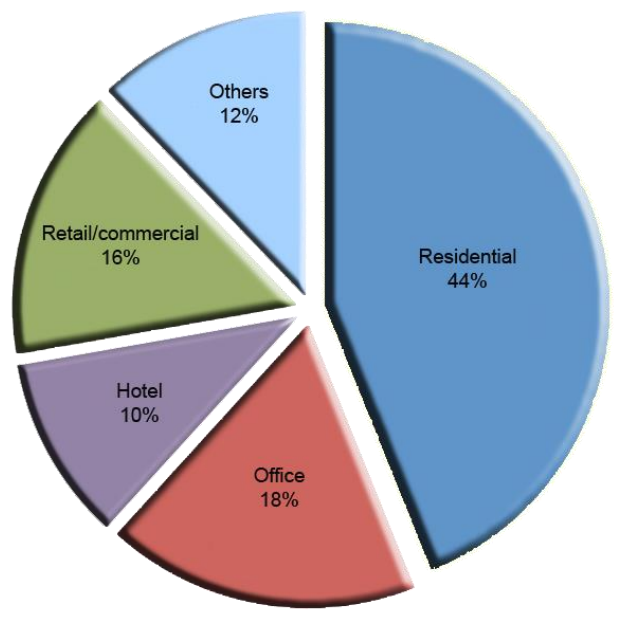

Fig. 4. Floor area proportion of TOD. (Source: CSID, 2019.)

Transit-Oriented Development is a design concept used to develop high-density urban areas by mixing residential, commercial, and offices (See Figs. 3 and 4) [19]. Furthermore, the areas were maximized using mass transportation equipment for pedestrians and bicycle lanes with public space and proximity to the nearest station designed as the community center [20,21]. The characteristics increase quality, accessibility and potential substance to create Land Value Capture (LVC) contexts. LVC is established based on the principle that land value is not only determined by intrinsic value and personal investment, but also by other external factors including change in land use regulation, public investment in infrastructure and public services, population and economic growth (see Fig. 5). In general, LVC is a mechanism where stakeholders responsible for the development of transportation infrastructure capture a portion of financial benefits gained by land developers or the community living around the infrastructure project [22]. TOD for LVC provides better access and connectivity, through integrated feeder buses or improves pedestrian access, through initiatives to provide better stations, with facilities filled with retail and other opportunities [23].

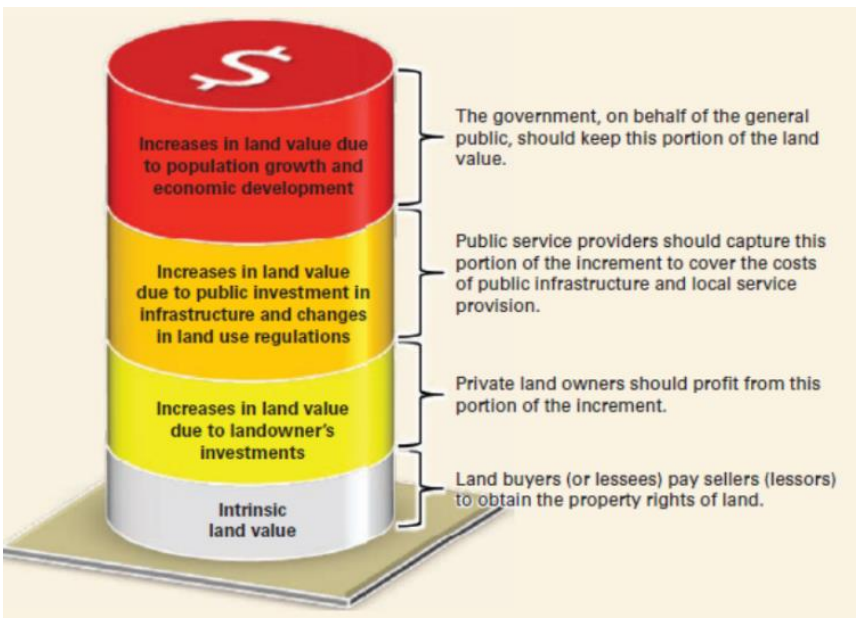

Fig. 5. Land value and its contribution. (Source: [22].)

\subsection{Residential Land Value Theory}

Land value prices are expected using hedonic analysis based on the comprehension that the value of the property is not entirely derived from its existence but also from the characteristics or the context of its location [24]. The characteristics included as explanatory variables in the hedonic method have two types including linkages of building structures and the land itself [15]. Case study for housing use the hedonic pricing method and available structural characteristics facilities support of residents' needs such as land, number of bedrooms, bathrooms, availability of garages, swimming pool, and other facilities that affect sales transactions [25]. The land characteristics which reflect its location and dependencies of the environmental condition generate the ease of accessibility, which subsequently increases its value [9]. According to Walsh (2007), neighborhood characteristics such as proximity to the open space area or green building calculate that the average household that lives $1 / 2$ mile from open space is willing to pay more than $\$ 4,104$ to reduce the distance to open space [26].

\section{Method and Data Source}

\subsection{Big Data/Web Scraping}

Data was collected using the Knowledge Discovery in Databases (KDD), with the mined data based on certain schemes [27]. There are many techniques used to analyze data. However, this study utilized the web scraping technique capable of amassing charts, pictures, texts, or other contain on a website [28], such as numerical and text data from lamudi.com using Parse Hub application. The data scraping process can be seen in Figs. 4 to 14. 


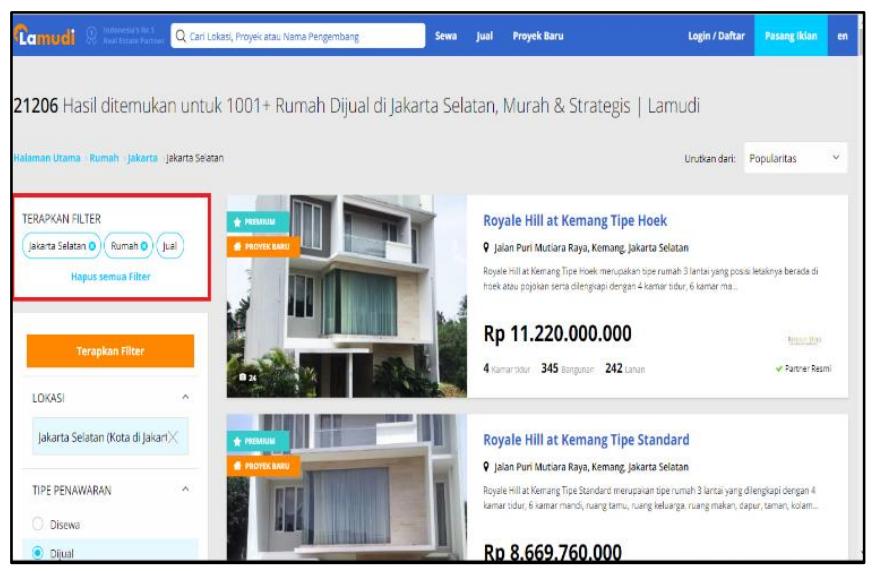

Fig. 6. lamudi.com website.

After installing the parse hub application on the computer, the initial step of the data memo process is selecting the website properties, the data of which to be retrieved from the application. The website used in this study is lamudi.com, an online real estate offering a secure and easy-to-use platform for sellers, buyers to find or list properties online (see Fig. 6).

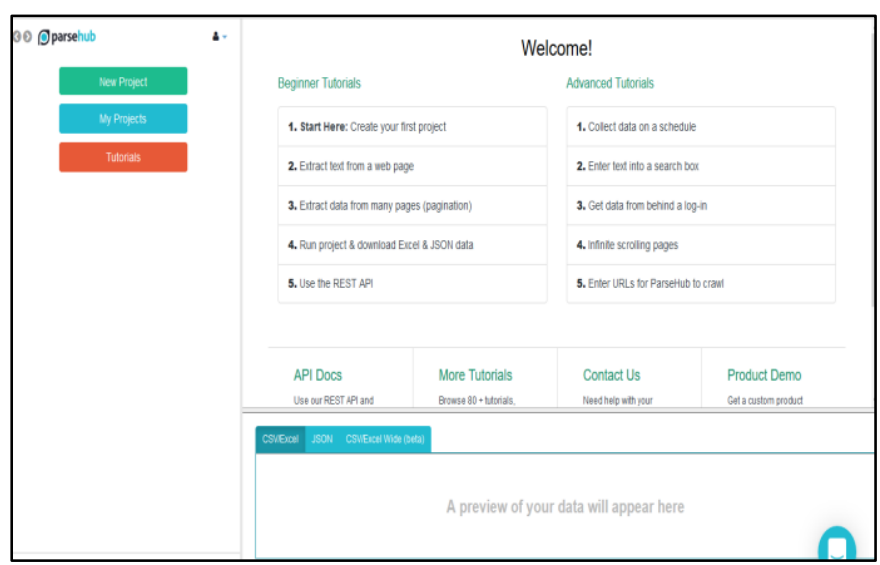

Fig. 7. Initial display of ParseHub application.

After opening the ParseHub application (see Fig. 7), the next step to be performed is copying the property website page link into the application (see Fig. 8), and starting a new project on its start page.

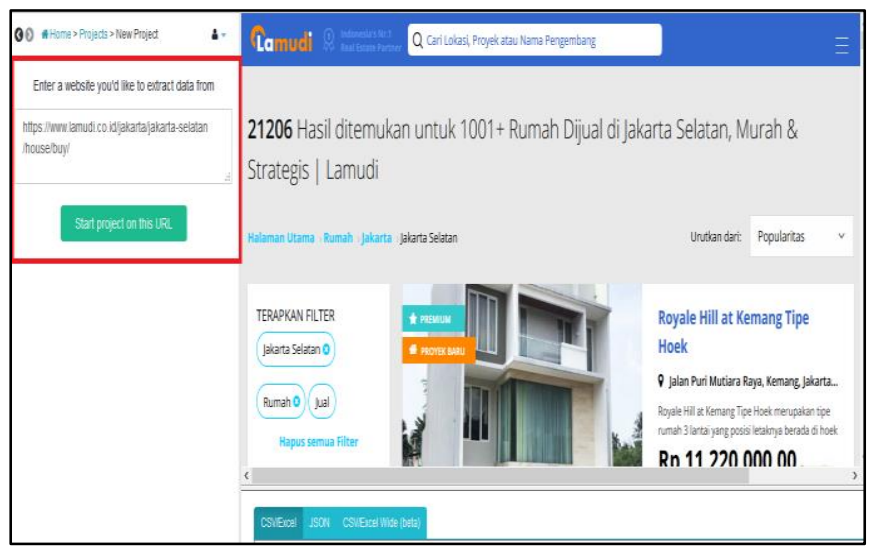

Fig. 8. Start the project on Parse Hub.

Every advertisement title contained on a page of the website is then selected by clicking them one by one (see
Fig. 9). Attribute data such as property address, price, number of bedrooms, number of bathrooms, building area and land area were taken by performing a process of relative select to each of these data (see Fig. 10).

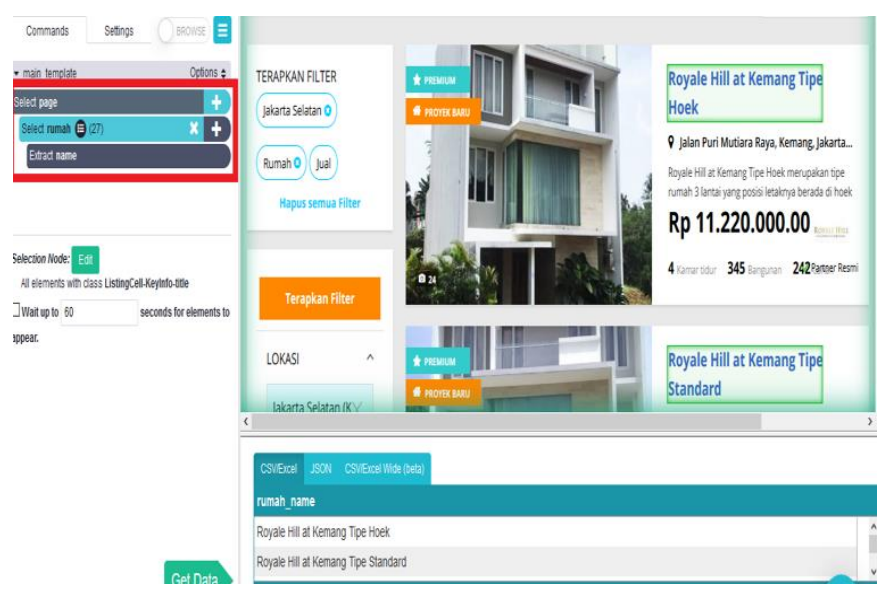

Fig. 9. Choose residential sales ad data.

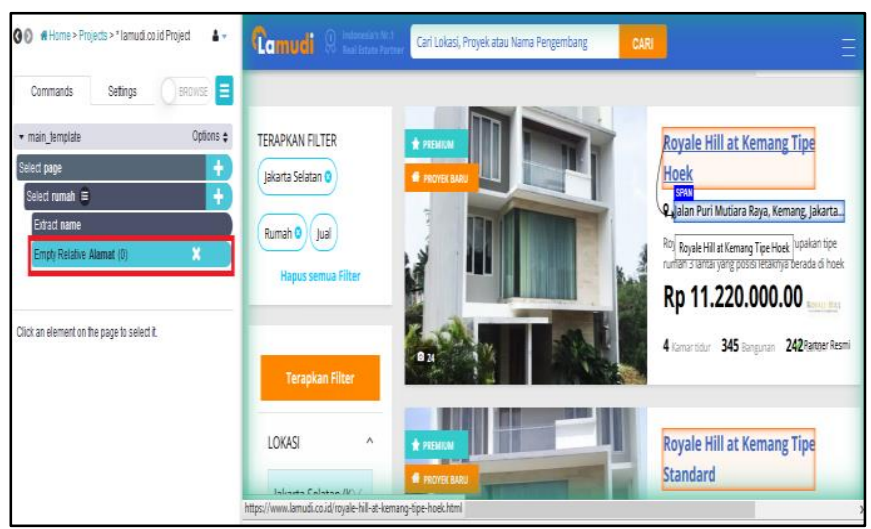

Fig. 10. Perform relative select according to the data needed.

If there is data that is not yet presented on the start page (for example, the number of bathrooms), then that data retrieval will be performed to get needed further detailed data (see Figs. 11 and 12).

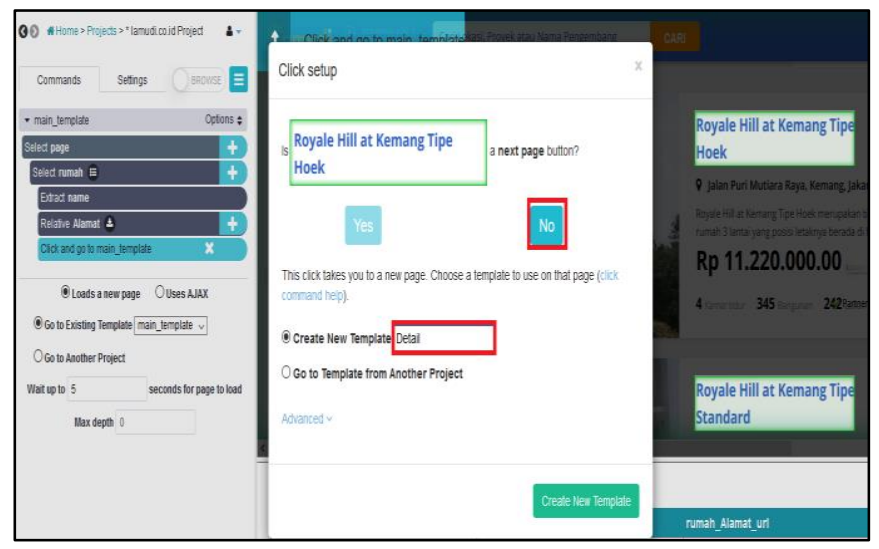

Fig. 11. Perform data retrieval details. 


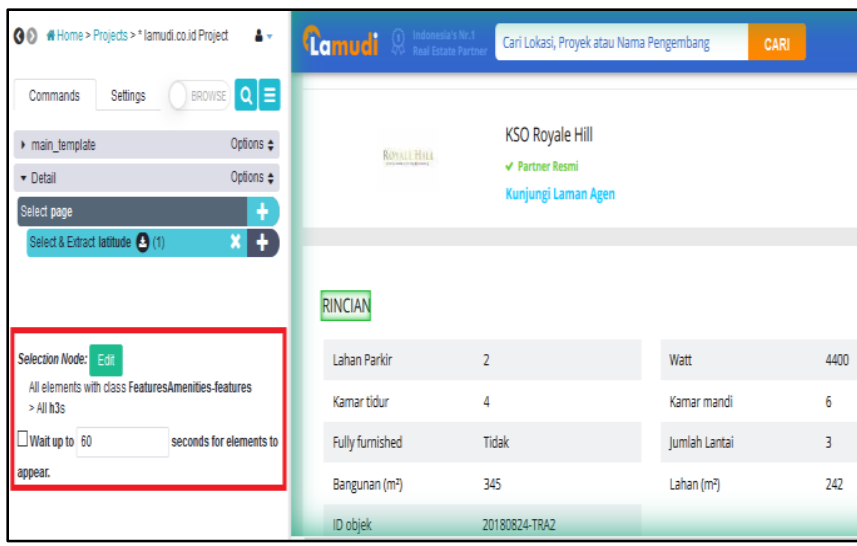

Fig. 12. Making data detailing templates.

Moreover, to get the coordinates of the location of the property in the form of latitude and longitude, the device for element inspection on the website page is activated beforehand, so that the latitude and longitude coordinate data can be selected and then extracted (see Figs. 13 and 14).

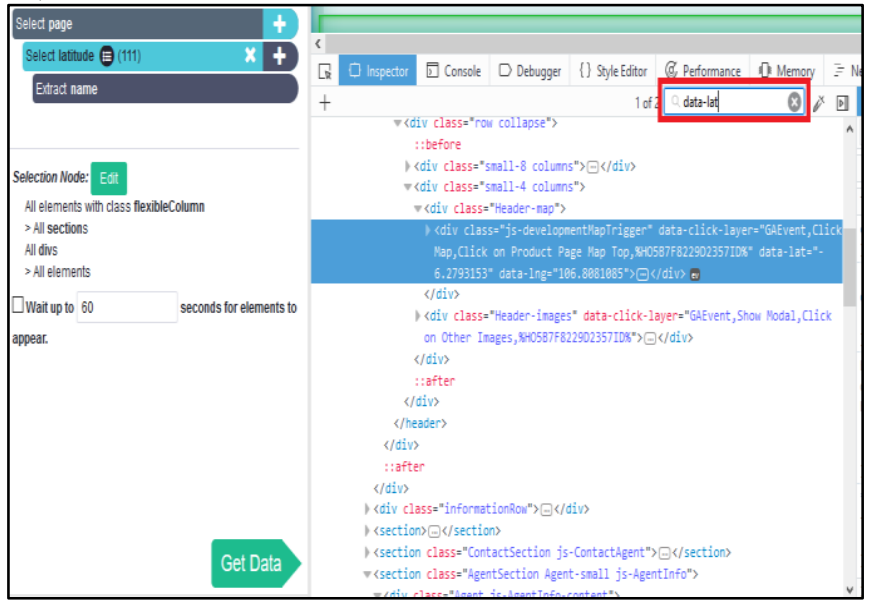

Fig. 13. Get latitude and longitude coordinates.

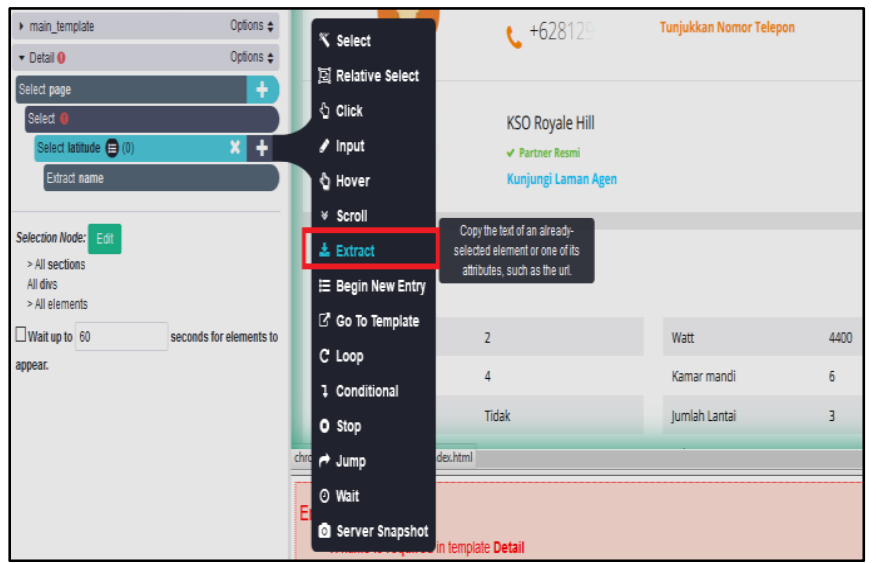

Fig. 14. Extract coordinates data.

After all of the data needed has been completely collected, they will be displayed in a tabular form that can be seen in Fig. 15 below.

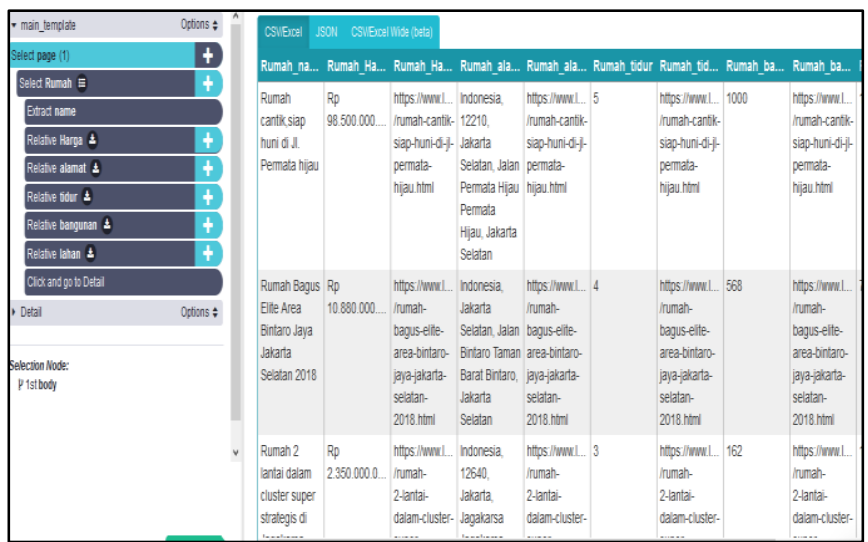

Fig. 15. Display data mining table.

Afterward, the next step to be done is clicking Get Data and Run buttons so that the data will be ready to be downloaded. Finally, in order to get the data presented in Excel format, the last step to be carried out is clicking download button (see Fig. 16).

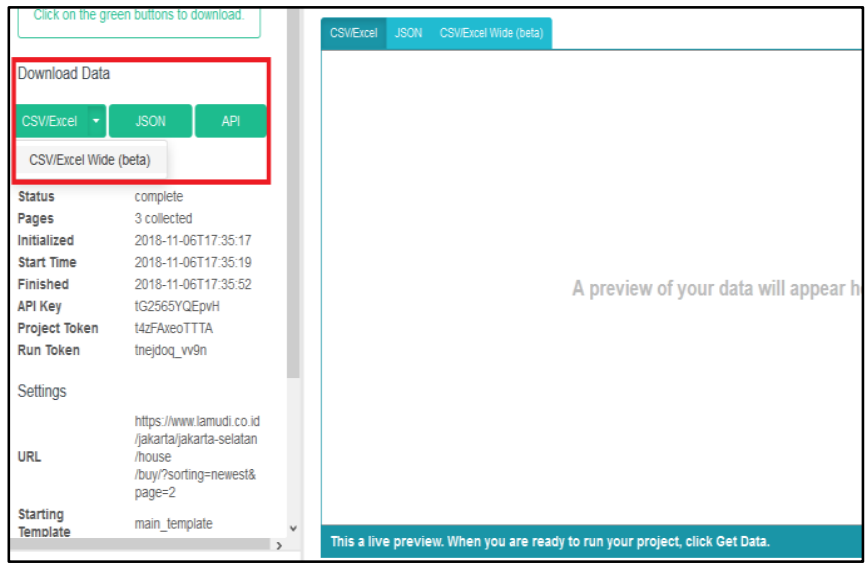

Fig. 16. Data ready to download.

The data mining was conducted from November 15th till December 2018, with a total of 1,751 properties located in South Jakarta. The data retrieved also contained structural attributes such as pricing/meter square, area, building, number of bedrooms and bathrooms, and the latitude/longitude coordinates. Furthermore, data screening and cleansing were carried out in order to get the data cleaned since there were several data that contained similar information. There were similarities because the website is always updated on a real time basis. Therefore, the pages keep changing containing different contents as the new advertisements for residential property sales uploaded to the website. The data cleansing process was carried out and filtered on excel format, which resulted in a total of 1,237 residential sales set free from similarity (see Fig. 17). 


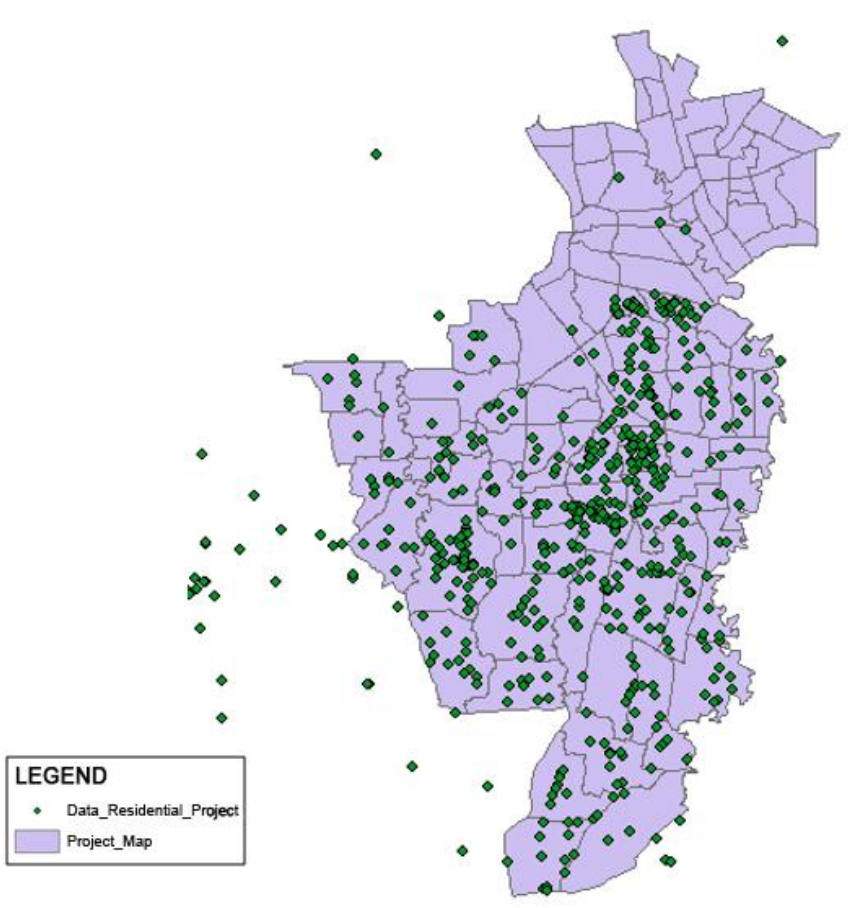

Fig. 17. Mapping residential data from the scraping process in ArcGIS.

\subsection{Mapping Data in ArcGIS}

The mapping of data in ArcGIS aims to obtain the research catchment area and distance of the residential properties to facilities which were determined according to the independent variables of the study. Previously, location data including latitude and longitude coordinates in residential areas were obtained through the web scraping process. Furthermore, other coordinates such as LRT, Mall, Hospital, School, Park, and CBD station locations were obtained through search coordinates on Google Maps.

After the data was collected, the first mapped coordinates of the residential location in ArcGIS, resulted in data of 1,237 properties spread throughout the South Jakarta area. Furthermore, the coordinates of LRT stations in the Dukuh Atas-Ciliwung LRT line including Dukuh Atas, Karet Kuningan, Rasuna Said, Kuningan, Cawang, Cikoko and Ciliwung stations were mapped. The coordinates of LRT stations were initially the benchmark which created a catchment area of $1 \mathrm{~km}$ by the TOD regulatory standard with boundary tools in ArcGIS. The catchment area is the scope of this research, therefore, in the end, the residential area numbering 1,237 data was not used, because its formation eliminated the residential outside $1 \mathrm{~km}$ from the LRT station and produced data of 105 residential properties processed from the equation of the hedonic price model (see Fig. 18). This was followed by distance measurements of the residential properties which were carried out at the nearest LRT station using the tools available in ArcGIS.

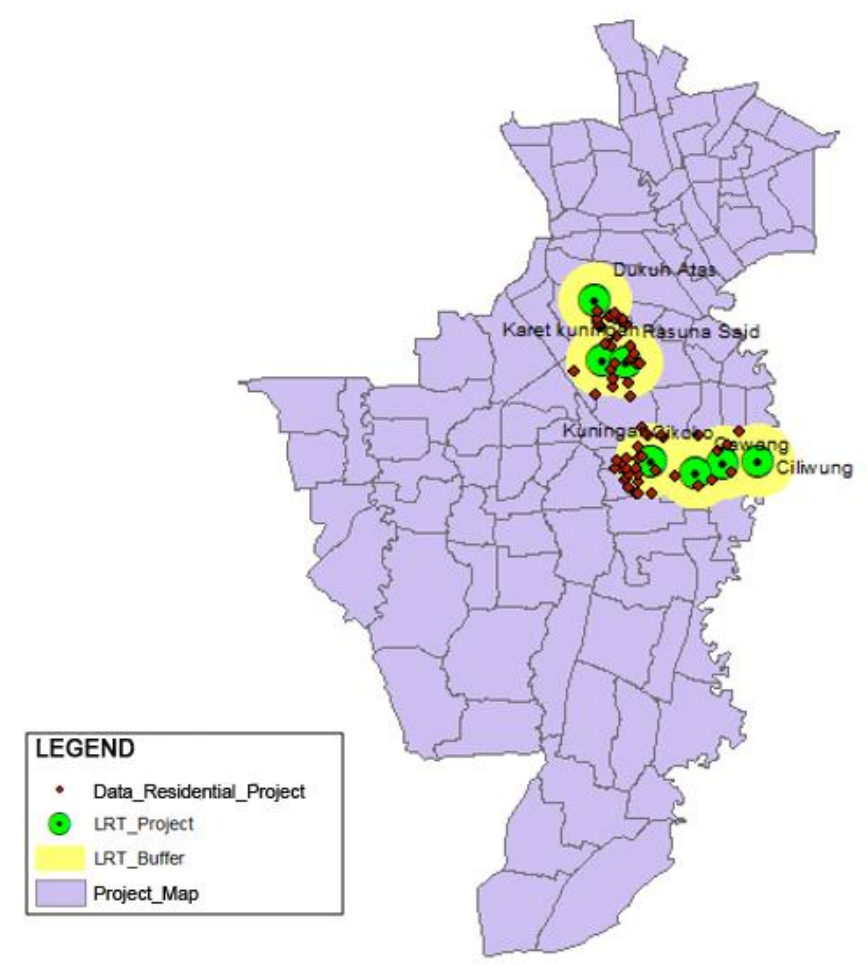

Fig. 18. Catchment Area $1 \mathrm{~km}$ from LRT Station.

Mapping was also conducted using the coordinates of the Mall, Hospital, School, Park and CBD location obtained from Google Maps. In accordance with Fig. 19, the distribution of facilities was both in and outside the research area. Similar to LRT stations, the calculation and distance of residential properties to the Mall, Hospital, School, Park, and the nearest CBD area were also calculated using the near tools in ArcGIS. 


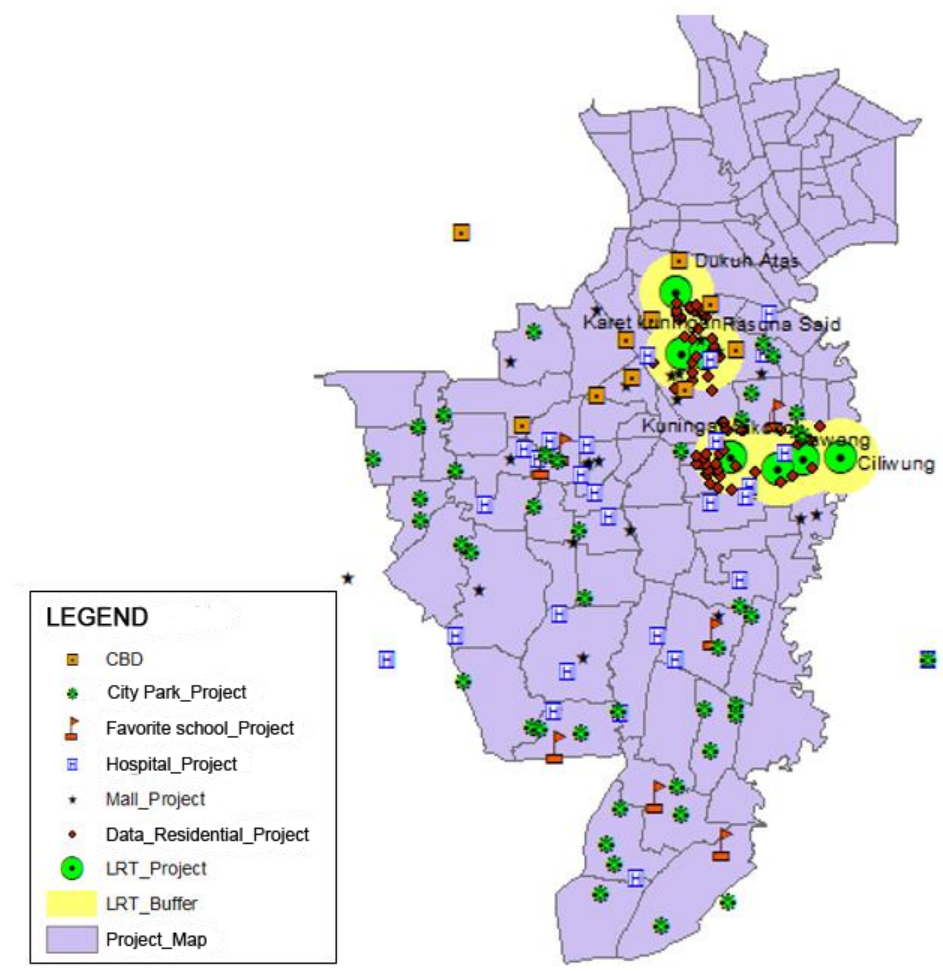

Fig. 19. Mapping data on ArcGIS.

\section{Result and Discussion}

Data result from ArcGIS was 105 within a distance of $1 \mathrm{~km}$ from the LRT station, which led to its disposal, also known as an outlier by filtering it deviant data. Furthermore, data with land price above IDR $100.000 .000 / \mathrm{m} 2$ were removed. Therefore, 101 were processed with SPSS.

Table 1. Descriptive statistics of the research data.

\begin{tabular}{lcrrrr}
\hline & N & \multicolumn{1}{c}{ Minimum } & Maximum & \multicolumn{1}{c}{ Mean } & Std. Deviation \\
\hline Price & 101 & $20,000,000.00$ & $69,000,000.00$ & $35,911,601.96$ & $11,699,215.41$ \\
Land_Area & 101 & 100.00 & 850.00 & 323.64 & 190.25 \\
Floor_Area & 101 & 110.00 & 1500.00 & 384.79 & 244.50 \\
Bed_room & 101 & 1.00 & 10.00 & 6.02 & 2.75 \\
Bath_room & 101 & 1.00 & 10.00 & 5.06 & 2.77 \\
LRT_Distance & 101 & 219.00 & 989.00 & 619.92 & 227.61 \\
Res_Mall & 101 & 0.00 & 1.00 & 0.60 & 0.49 \\
Res_Hospital & 101 & 0.00 & 1.00 & 0.74 & 0.44 \\
Res_School & 101 & 0.00 & 1.00 & 0.01 & 0.10 \\
Res_Park & 101 & 0.00 & 1.00 & 0.23 & 0.42 \\
Res_CBD & 101 & 0.00 & 1.00 & 0.58 & 0.50 \\
Valid N & 101 & & & & \\
(listwise) & & & & & \\
\hline
\end{tabular}

The results obtained shows (see Table 1 ) that the lowest residential price value is IDR $20,000,000 / \mathrm{m} 2$ in Mampang area, while the highest is IDR $69,000,000 / \mathrm{m} 2$ in Kemang area, with an average price of IDR $35,911,602 / \mathrm{m} 2$. The lowest land area based on the above results is $100 \mathrm{~m} 2$, and the highest is $850 \mathrm{~m} 2$, while the lowest building area is $110 \mathrm{~m} 2$ and the highest is $1,500 \mathrm{~m} 2$ with an average land area of $323 \mathrm{~m} 2$ and building area of $384 \mathrm{~m} 2$. The minimum number of bedroom and bathroom area is 1 , while the maximum number is 10 with an average of six bedrooms and five bathrooms. The distance of the residential property to the nearest LRT station is $219 \mathrm{~m}$, and the farthest is $989 \mathrm{~m}$ with an average distance of $619 \mathrm{~m}$. Furthermore, the dummy variables, such as the existence of Mall, Hospital, School, Park, and $\mathrm{CBD}$ at a distance of $1 \mathrm{~km}$ had the highest value of 1 for proximity less than $1,000 \mathrm{~m}$ and the lowest value 0 for proximity more than $1,000 \mathrm{~m}$. 
Pearson Correlation test was also carried out to determine the relationship between two variables with a significant value below 0.05 . Two variables are stated to be correlated when changes in one variable are accompanied by changes in other variables, both in the same direction or the opposite direction. Although the correlation coefficient value is small (not significant) it does not mean that the two variables are not interconnected. The two variables may have a strong close relationship, but the correlation coefficient value is close to zero, for example in the case of non-linear relationships. Thus, the correlation coefficient only measures the strength of the linear relationship and not the non-linear relationship [29]. The magnitude of value correlation is determined based on Table 2 .

Table 2. Correlation Value.

\begin{tabular}{lc}
\hline r value & Correlation \\
\hline $0.00-0.25$ & Weak \\
$0.26-0.50$ & Moderate \\
$0.51-0.75$ & Strong \\
$0.76-1$ & Very strong \\
\hline
\end{tabular}

Table 3. Pearson Correlation: Dependent Variable vs Independent Variable.

\begin{tabular}{lccc}
\hline & \multicolumn{2}{c}{ Ln Price } \\
\hline & $\begin{array}{c}\text { Pearson } \\
\text { Correlation }\end{array}$ & Sig. & N \\
\hline Ln_Price & 1 & & 101 \\
Land_Area & 0,094 & 0,350 & 101 \\
Floor_Area & 0,103 & 0,306 & 101 \\
Bed_room & $.427^{* *}$ & 0,000 & 101 \\
Bath_room & $.410^{* *}$ & 0,000 & 101 \\
LRT_Distance & 0,071 & 0,481 & 101 \\
Res_Mall & $.845^{* *}$ & 0,000 & 101 \\
Res_Hospital & $.425^{* *}$ & 0,000 & 101 \\
Res_School & 0,001 & 0,989 & 101 \\
Res_Park & $.407^{* *}$ & 0,000 & 101 \\
Res_CBD & $.819^{* *}$ & 0,000 & 101 \\
\hline
\end{tabular}

According to the previous result (see Table 3), independent variables have a relationship to residential prices in accordance with the structure, number of bedrooms and bathrooms on the medium level. The neighborhood attributes that affect the residential price are the proximity to Mall and CBD areas on the highest level, thereby increasing the value of the property. Besides, proximity to hospitals and parks also has a positive relationship to a moderate level.

Table 3 also describes the relationship between the independent variables of structure attributes. Moreover, the number of bedrooms is positively related to bathrooms, as well as land and building areas. Furthermore, neighborhood attributes are negatively correlated to the distance to LRT and proximity to the Hospital, since operations of the stations tend to disturb the hospitals. Therefore, their locations are far apart. Another case with proximity is the mall and CBD area with strong positive correlation, by the current condition, which is usually in a crowded area or the centre of the city.

\section{Conclusion}

The price of residential property in catchment area 1 $\mathrm{km}$ around the stations in LRT Dukuh Atas-Ciliwung line is positively correlated with the number of bedrooms and bathrooms, with significant values of 0.427 and 0.410 at the moderate level. The result is similar to the previous study in the City of Atlanta and DeKalb, where neither neighborhood attributed to the proximity of residencies to hospitals and parks within $1 \mathrm{~km}$ which are positively correlated to significant values of 0.425 and 0.407 indicating a moderate correlation. Therefore, the most correlated variables increased residential property values as well as proximity to malls and $\mathrm{CBD}$ areas with significant values of 0.845 and 0.819 . Unfortunately, this study did not produce the correlation between residential property values and proximity to LRT, which was proven by a significant value of 0.071 . This occurred because people still utilized the old techniques and effects of being so close to the rail transit. Therefore, proximity to LRT stations has not been used as a variable that affects the land value, even though the LRT is designed in such a way that it is environmentally friendly using the U-Shaped Girder capable of reducing noise to approximately 15 decibels [30].

\section{Acknowledgement}

This research was supported by research grant from Universitas Indonesia [grant number NKB1724/UN2.RST/HKP.05.00/2020].

\section{References}

[1] Badan Pusat Statistik (BPS). Jumlah Penumpang Kereta Api. (2018). Accessed: July 20, 2019. [Online]. Available:

https://www.bps.go.id/statictable/2009/03/06/14 14/jumlah-penumpang-dan-barang-melaluitransportasi-kereta-api-indonesia-tahun-19872017.html

[2] PT Kereta Commuter Indonesia. Sekilas PT Kereta Commuter Indonesia. (2018). Accessed: July 20, 2019. [Online]. Available: http://www.krl.co.id/

[3] tradingeconomics.com BI. Indonesia Residensial Property Price Index - Forecast 2018. Accessed: July 20, 2019. [Online]. Available: https://id.tradingeconomics.com/indonesia/housin g-index

[4] M. Zhang and T. Xu, "Uncovering the potential for value capture from rail transit services," J. Urban Plan. Dev., vol. 143, no. 3, p. 04017006, 2017. [Online]. Available: https://doi.org/10.1061/(asce)up.19435444.0000383

[5] H. W. Batt, "Value capture as a policy tool in transportation economics: An exploration in public 
finance in the tradition of Henry George," Am. J. Econ. Sociol., vol. 60, no. 1, pp. 195-228, 2001. [Online]. Available: https://doi.org/10.1111/15367150.00061

[6] R. Cervero and M. Duncan, “Transit's value-added effects: Light and commuter rail services and commercial land values," Transp. Res. Rec., vol. 1805, no. 1, pp. 8-15, 2002. [Online]. Available: https://doi.org/10.3141/1805-02

[7] H. Du and C. Mulley, "Understanding spatial variations in the impact of accessibility on land value using geographically weighted regression," J. Transp. Land Use, vol. 5, no. 2, pp. 46-59, 2012. [Online]. Available: https://doi.org/10.5198/jtlu.v5i2.225

[8] House of Commons, Transport Committee, "Rail infrastructure investment" Fourth Report of Session 2017-19 Report, together with formal minutes relating to the report, 2018.

[9] J. Landis, S. Guhathakurta, W. Huang, M. Zhang, B. Fukuji, and S. Sen, Rail Transit Investments, Real Estate $V$ alues, and Land Use Change: A Comparative Analysis Of Five California Rail Transit Systems. University of California at Berkeley, 1995.

[10] J. Chamberlain, "Funding railway infrastructure when there is no magic money tree," Glob. Railw. Rev., 2017. Accessed: July 20, 2019. [Online]. Available:

https://www.globalrailwayreview.com/article/6362 2/ funding-railway-infrastructure/

[11] M. Iacono, A. Lari, D. Levinson, and Z. J. Zhao, "Value capture for transportation finance: technical research report," Cent. Transp. Stud. Rep., CTS 0918, 2009.

[12] N. Baum-Snow and M. E. Kahn, "The effects of new public projects to expand urban rail transit," J. Public Econ., vol. 77, no. 2, pp. 241-263, 2000. [Online]. Available: 2727(99)00085-7

[13] R. Sharma and P. Newman, "Can land value capture make PPP's competitive in fares? A Mumbai case study," Transp. Policy, vol. 64, pp. 123-131, 2018. [Online].

Available: https://doi.org/10.1016/j.tranpol.2018.02.002

[14] G. Debrezion, E. Pels, and P. Rietveld, "The impact of railway stations on residential and commercial property value: A meta-analysis," J. Real Estate Financ. Econ., vol. 35, pp. 161-80, 2007. [Online]. Available: https://doi.org/10.1007/s11146-007-9032-z

[15] D. R. Bowes and K. R. Ihlanfeldt, "Identifying the impacts of rail transit stations on residential property values," J. Urban Econ., vol. 50, pp. 1-25, 2001. [Online]. https://doi.org/10.1006/juec.2001.2214

[16] M. Antrop, "Why landscapes of the past are important for the future," Landsc. Urban Plan., vol. 70 no. 1-2, pp. 21-34, 2005. [Online]. Available: https://doi.org/10.1016/j.landurbplan.2003.10.002

[17] Asian Development Bank (ADB). Urban development: Issues, challenges, and ADB's Approach. Urban Dev.
(2018). Accessed: July 20, 2019. [Online]. Available: https://www.adb.org/themes/urbandevelopment/issues

[18] Educalingo. Meaning of Urban Development. Urban Dev. (2018). Accessed: July 20, 2019. [Online]. Available: https://educalingo.com/en/dic-en/urbandevelopment

[19] M. A. Berawi, B. E. Ibrahim, G. Gunawan, and P. Miraj, "Developing a conceptual design of transitoriented development to improve urban land use planning," J. Des. Built Environ., vol. 19, no. 1, pp. 4048, 2019.

[20] F. Dolnick and M. Davidson, A Glossary of Zoning, Development, and Planning Terms. American Planning Association, 1999.

[21] R. Thomas, D. Pojani, S. Lenferink, L. Bertolini, D Stead, and E. van der Krabben, "Is transit-oriented development (TOD) an internationally transferable policy concept?," Reg. Stud., vol. 52, no. 9, pp. 12011213, 2018. [Online]. Available: https://doi.org/10.1080/00343404.2018.1428740

[22] H. Suzuki, J. Murakami, Y.-H. Hong, and B. Tamayose, "Financing transit-oriented development with land values: Adapting land value capture in developing countries," The World Bank, 2015.

[23] A. Abiad, K. Farrin, and C. Hale, "Sustaining transit investment in Asia's cities: A beneficiary-funding and land value capture perspective," ADB, 2019.

[24] Y. Kestens, M. Thériault, and F. Des Rosiers, "The impact of surrounding land use and vegetation on single-family house prices," Environ. Plan B Plan Des., vol. 31, no. 4, pp. 539-567, 2004. [Online]. Available: https://doi.org/10.1068/b3023

[25] M. A. Berawi, N. Suwartha, K. Kurnia, G. Gunawan, P. Miraj, and A. R. B. Berawi, "Forecasting the land value around commuter rail stations using Hedonic price modeling," Int.J. Technol., vol. 9, pp. 1329-1337, 2018. [Online]. Available: https://doi.org/10.14716/ijtech.v9i7.2589

[26] R. Walsh, "Endogenous open space amenities in a locational equilibrium," J. Urban Econ., vol. 61, no. 2, pp. 319-344, 2007. [Online]. Available: https://doi.org/10.1016/j.jue.2006.09.002

[27] X. Wu, X. Zhu, G. Q. Wu, and W. Ding, "Data mining with big data," IEEE Trans. Knowl. Data Eng., vol. 26, no. 1, pp. 97-107, 2014. [Online]. Available: https://doi.org/10.1109/TKDE.2013.109

[28] D. Fawzy, S. Moussa, and N. Badr, "The evolution of data mining techniques to big data analytics: An extensive study with application to renewable energy data analytics," Asian J. Appl. Sci., vol. 4, no. 3, 2016.

[29] J. Lani, Correlation (Pearson, Kendall, Spearman). Stat Solut, 2010.

[30] LRT Jabodebek. "Sifat Sound Barrier. U Shaped Girder." Lrtjabodebek.Com. (2018). Accessed: July 20, 2019. [Online]. Available: http://lrtjabodebek.com/sifat-sound-barrier-ushaped-girder/ 


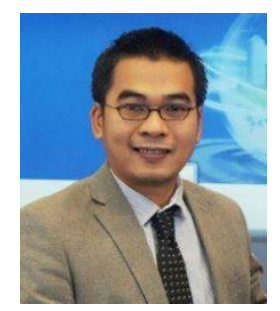

Dr. Mohammed Ali Berawi is an associate professor at department of civil engineering, Universitas Indonesia. He has extensive research experience regarding value engineering and innovation in infrastructure, construction, and manufacturing industry. He has been listed by Webometrics as one of the Top Scientists in Indonesia (2015-2017), Top 500 Indonesian Best Researchers by Ministry of Research and Technology of the Republic of Indonesia (2020), and his biography was featured in the 24th edition of Who's Who in the World. Dr. Berawi served as Lead Advisor to the Republic of Indonesia's Ministry of Transportation (2012), Director of Directorate of Research and Community Services at the Universitas Indonesia (2015), and currently serves as Chairman of Standing Committee on Infrastructure Strategic Policies for Indonesia Chamber of Commerce (KADIN Indonesia), Executive Director of the Center for Sustainable Infrastructure Development (CSID) Universitas Indonesia, and Director of Association of Southeast Asian Nations (ASEAN) University Network for Sustainable City and Urban Development (AUN - SCUD).

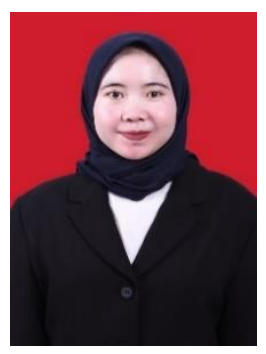

Lusi Aprianti was born in Tegal, Central Java, Indonesia, 1997. She received the Bachelor Degree in Universitas Indonesia, in 2019 as Civil Engineer. In 2019, she became Runner Up of Project Estimation Simulation on Civil National Competition and Seminar (CNCS) UNPAR 2019 and Runner Up of Design Tender Competition on ITB Civil Engineering Expo (ICEE) 2018.

Gunawan Saroji, photograph and biography not available at the time of publication.

Mustika Sari, photograph and biography not available at the time of publication.

Perdana Miraj, photograph and biography not available at the time of publication.

Amy A. Kim, photograph and biography not available at the time of publication. 